\title{
Ductal Epithelial Cell
}

National Cancer Institute

\section{Source}

National Cancer Institute. Ductal Epithelial Cell. NCI Thesaurus. Code C12479.

A stratified columnar epithelial cell that surrounds a lumen in a gland such as the breast, pancreas or prostate. These cells are uniform in appearance and have uniformly sized and shaped nuclei. 